\title{
Kebijakan yang Dilakukan oleh PT. Kimia Farma, Tbk (KAEF) dalam Meningkatkan Produktivitas dan Pendapatannya
}

\author{
Hery Haryanto $^{* 1}$, Eddy Oktarianto ${ }^{2}$, Junita $^{3}$, Andryanto $^{4}$, Rudiyanto ${ }^{5}$ \\ 1,2,3,4,5 Manajemen, Fakultas Ekonomi, Universitas Internasional Batam, Indonesia \\ Email: 'hery.haryanto@uib.edu, ${ }^{2} 2041120 . e d d y @ u i b . e d u,{ }^{3} 2041122 . j u n i t a @ u i b . e d u$, \\ 42041156.andryanto@uib.edu, ${ }^{5} 2041280$. rudiyanto@uib.edu
}

\begin{abstract}
Abstrak
Tujuan penelitian ini adalah untuk mengetahui berbagai kebijakan yang dikeluarkan oleh Kimia Farma dalam meningkatkan produktivitas dan meningkatkan pendapatan perusahaan, serta untuk melakukan analisa terhadap kebijakan perusahaan dalam menghadapi berbagai permasalahan, baik itu permasalahan yang bersifat domestik maupun itu permasalahan dunia dimasa sekarang ini, contohnya seperti adanya pandemi COVID-19. Dalam melakukan peneltian terhadap PT. Kimia Farma, peneliti menggunakan metode pengambilan data secara dokumentasi. Hal ini dikarenakan metode ini merupakan sebuah metode yang digunakan dalam penelitian dengan melakukan pengumpulan berbagai data yang diperlukan secara lengkap dan kompleks. Hasil penelitian menyimpulkan bahwa untuk mendapatkan kembali kepercayaan masyarakat, pihak Kimia Farma ini langsung melakukan evaluasi serta melakukan penguatan terhadap pelaksanaan SOP (Standard Operating Procedure) dengan tujuan untuk memastikan bahwa seluruh dari kegiatan operasional perusahaann sudah sesuai ketentuan yang telah ditentukan dan yang pasti nya ketentuan tersebut berlaku. Kebijakan ini diambil oleh pihak Kimia Farma adalah sebagai upaya untuk melakukan pencegahan terhadap kejadian serupa tidak terjadi lagi.
\end{abstract}

Kata kunci: Farmasi, KAEF, Kimia Farma, Pendapatan, Produktivitas.

\begin{abstract}
The purpose of this study is to find out the various policies issued by Kimia Farma in increasing productivity and increasing company revenues, as well as to analyze company policies in dealing with various problems, both domestic problems and current world problems, for example, the COVID-19 pandemic. In conducting research on PT. Kimia Farma, researchers use the method of data collection in a documentation. This is because this method is a method used in research by collecting various data needed in a complete and complex manner. The conclusion from the conclusion is that to regain public trust, Kimia Farma immediately evaluates and continues the implementation of the SOP (Standard Operating Procedure) with the aim of ensuring that all operational activities of the company are in accordance with the provisions that have been determined and of course these provisions apply. This policy was taken by Kimia Farma as an effort to prevent similar incidents from happening again.
\end{abstract}

Keywords: Income, KAEF, Kimia Farma, Pharmacy, Productivity.

\section{PENDAHULUAN}

PT. Kimia Farma Tbk. (KAEF) adalah perseroan industri yang fokus pada industri farmasi. Perusahaan ini merupakan perusahaan yang didirikan oleh Pemerintah Hindia Belanda dan menjadi perusahaan atau industri farmasi pertama yang didirikan di Indonesia (Sesyazhade et al., 2018). Tahun 1958, pemerintah Republik Indonesia menggelompokkan beberapa perseroan farmasi menjadi "Perusahaan Farmasi Nasional (PNF) Bhinneka Kimia Farma" dimana ini sesuai dengan kebijakan nasionalisasi perusahaan asli yang didirikan oleh Pemerintah Hindia Timur Belanda, dan kemudian berbadan hukum PNF diubah lagi oleh pemerintah Republik Indonesia Sebagai perseroan terbatas, nama perusahaan diubah menjadi PT Kimia Farma (Persero) pada tanggal 16 Agustus 1971 (Walintukan, 2019). Tanggal 4 Juli 2001, Kimia Farma mengubah statusnya dari perusahaan terbatas menjadi perusahaan publik dengan nama PT Kimia Farma (Persero), Tbk (KAEF) (Caniago, 2017). 
Kimia Farma menyajikan 6 strategi untuk mendukung pertumbuhan dan perkembangan perusahaan dalam jangka panjang melalui anak perusahaan Kimia Farma Apotek dan Kimia Farma Diagnostika. Berikut ini merupakan strategi-strategi yang dimaksudkan (Mulyana, 2021):

1. Model Bisnis Digital Baru, melalui integrasi toko fisik dan online dengan strategi omni-channel, integrasi laboratorium farmasi-klinik-diagnostik, dan saluran digital baru.

2. Strategi Kerjasama, yakni menjalin kerjasama dengan berbagai perusahaan mitra bisnis yang saling menguntungkan kedua belah pihak.

3. Pengalaman Operasi dan Layanan yang Sangat Baik, termasuk berbagai prinsip, sistem dan alat yang mengarah pada perbaikan berkelanjutan melalui penerapan strategi untuk menciptakan nilai keunggulan dalam setiap proses operasional.

4. Manajemen Hubungan Pelanggan, dengan meningkatkan hubungan layanan pelanggan dan membantu mempertahankan pelanggan, serta mendorong pertumbuhan penjualan.

5. Penjualan dan Strategi Pendapatan Lainnya, meningkatkan pendapatan lainnya dengan memilih produk yang tepat dan menggunakan aset dalam jumlah, tempat dan waktu yang tepat.

6. Efektivitas Biaya, dengan meninjau dan mengendalikan semua biaya langsung atau tidak langsung untuk menyediakan produk dan layanan yang terjangkau.

Dengan memiliki pengalaman yang berpuluhan tahun, Kimia Farma kini tumbuh dan berkembang pesat menjadi perusahaan farmasi dengan layanan kesehatan yang komprehensif di Indonesia (Sampurno, 2021). Kimia Farma semakin dipertimbangkan untuk turut serta mendorong pembangunan dan pembangunan negara, terutama pembangunan bidang kesehatan masyarakat Indonesia (kimiafarma.co.id, 2015).

Tujuan penelitian ini adalah untuk mengetahui berbagai kebijakan yang dikeluarkan oleh Kimia Farma dalam meningkatkan produktivitas dan meningkatkan pendapatan perusahaan, serta untuk melakukan analisa terhadap kebijakan perusahaan dalam menghadapi berbagai permasalahan, baik itu permasalahan yang bersifat domestik maupun itu permasalahan dunia dimasa sekarang ini, contohnya seperti adanya pandemi COVID-19.

Dengan adanya analisa terhadap kebijakan yang akan dikeluarkan oleh perusahaan, maka kebijakan tersebut dapat menyelesaikan berbagai permasalahan dan mampu meningkatkan produktivitas dari perusahaan sehingga bisa meningkatkan pendapatan perusahaan.

Manfaat yang bisa dapatkan dari penulisan artikel ini terhadap pembaca adalah sebagai berikut:

1. Menjadi sumber informasi yang bisa membantu pembaca dalam mengambil suatu keputusan.

2. Mampu meningkatkan pengetahuan serta pemahaman pembaca terhadap kebijakan yang bisa dilakukan untuk mengatasi permasalahan sehingga dapat meningkatkan produktivitas serta pendapatan suatu perusahaan.

\section{METODE PENELITIAN}

Dalam melakukan penelitian terhadap PT Kimia Farma, peneliti menggunakan data primer. Berdasarkan cara memperoleh data-data dari PT Kimia Farma, peneliti memperoleh data tersebut dari internet tanpa mendapatkan data-data yang diperlukan dari sumber-sumber yang lain. Dalam melakukan peneltian terhadap PT. Kimia Farma, peneliti menggunakan metode pengambilan data secara dokumentasi. Hal ini dikarenakan metode ini merupakan sebuah metode yang digunakan dalam penelitian dengan melakukan pengumpulan berbagai data yang diperlukan secara lengkap dan kompleks. Peneliti menggunakan metode pengambilan data secara dokumentasi data-data yang diperoleh dari sumber lain merupakan data fakta yang tersimpan dalam bentuk dokumentasi. Metode pengambilan data dengan jenis dan kategori ini menurut tim peneliti sangat cocok untuk melakukan penelitian terhadap PT Kimia Farma yang bertujuan untuk mengetahui berbagai kebijakan yang dikeluarkan oleh Kimia Farma dalam meningkatkan produktivitas dan meningkatkan pendapatan perusahaan, serta untuk melakukan analisa terhadap kebijakan perusahaan dalam menghadapi berbagai permasalahan, baik itu permasalahan yang bersifat domestik maupun itu permasalahan dunia dimasa sekarang ini, contohnya seperti adanya pandemi COVID-19. 


\section{HASIL DAN PEMBAHASAN}

Untuk permasalahan pertama, yaitu turunnya daya beli masyarakat yang di akibatkan oleh pandemi COVID-19. GM (General Manager) Pengembangan Bisnis Kimia Farma yang bernama Wisnu Sucahyo menyatakan bahwa Kimia Farma tidak luput dari adanya dampak pandemi COVID-19, terutama berdampak pada kinerja perusahaan. Akibat adanya kebijakan yang dikeluarkan oleh pemerintah tentang Pembatasan Sosial Berskala Besar (PSBB) dimana kebijakan tersebut menyebabkan menurunnya daya beli oleh masyarakat. Akibat dari pandemi tersebut sangat berpengaruh sehingga menyebabkan menurunnya masyarakat membeli obat di apotek dan rumah sakit (Nursyamsi \& Pratiwi, 2020).

Mengenai permasalahan pertama yang sedang dihadapi, Kimia Farma membuat kebijakan dengan melakukan berbagai upaya yang diharapkan bisa beradaptasi sekaligus bisa menjadikan permasalahan ini sebagai peluang yang bisa diambil pada masa pandemi COVID-19. Upaya yang dilaksanakan Kimia Farma ini adalah dengan meluncurkan aplikasi digital yang bernama Kimia Farma Mobile, dimana aplikasi ini dikembangkan oleh Kimia Farma Apotek yang merupakan anak usaha dari Kimia Farma. Harapan dari aplikasi Kimia Farma Mobile ini adalah dapat menjadi sebagai solusi terkait penyediaan layanan kesehatan dimana aplikasi ini bisa digunakan oleh masyarakat dalam memperoleh bantuan serta kebutuhan mengenai kesehatan tubuh di masa pandemi.

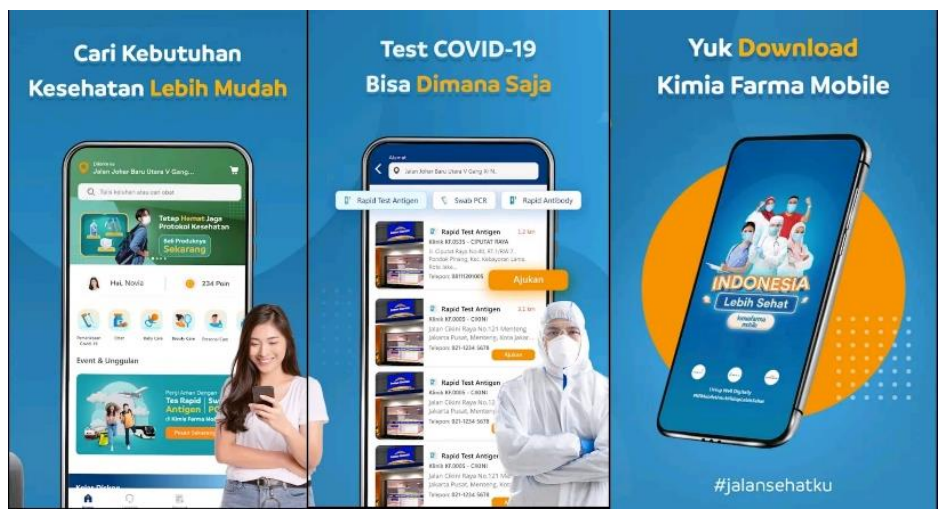

Gambar 1. Poster aplikasi digital "Kimia Farma Mobile"
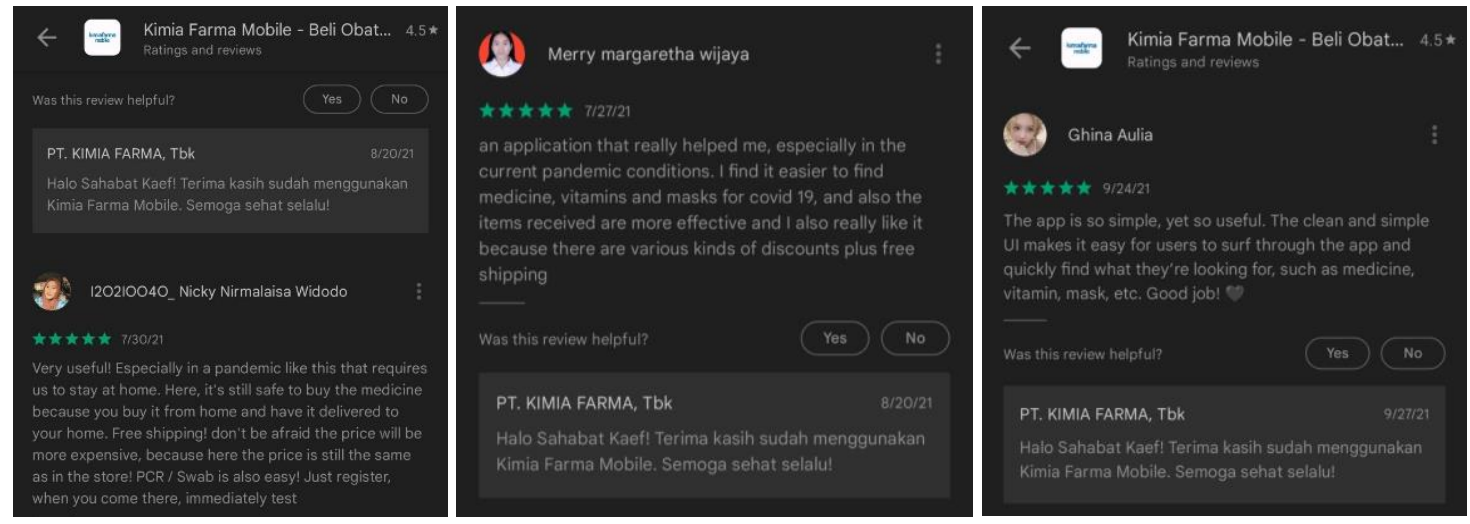

Gambar 2. Feedback dari pengguna aplikasi "Kimia Farma Mobile"

Kemudian, Kimia Farma sekarang ini juga sedang melakukan upaya untuk memberikan layanan home service bagi para pasien yang mengalami keterbatasan dalam mengunjungi apotek Kimia Farma terdekat. Dengan kebijakan-kebijakan yang sudah dilakukan, Kimia Farma berharap bisa kembali mencatat kinerja laporan keuangan yang lebih bagus sebelum adanya kebijakan yang dilakukan. 


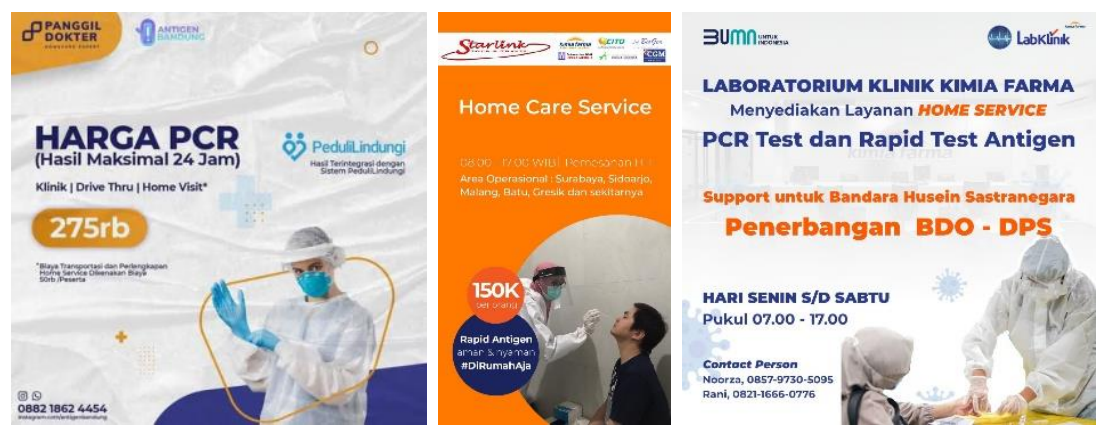

Gambar 3. Poster pelayanan home service klinik kimia farma

Untuk permasalahan kedua terkait kinerja keuangan perusahaan yang menurun akibat adanya oknum pegawai atau petugas yang menggunakan antigen COVID-19 bekas kepada calon penumpang pesawat, dimana oknum tersebut adalah karyawan dari Kimia Farma Diagnostika (KFD) yang merupakan anak perusahaan dari perusahaan Kimia Farma. Kebijakan yang diambil oleh Erick Thohir selaku Menteri BUMN adalah dengan melakukan pemecatan terhadap seluruh direksi daripada PT. Kimia Farma Apotek, yang dimana saham dari PT tersebut dimiliki oleh BUMN farmasi. Untuk diketahui bahwa kasus ini mulai terungkap setelah pihak kepolisian mendapatkan keluhan dari para calon penumpang pesawat dimana mereka memperoleh bahwa hasil dari rapid antigennya positif COVID-19 dalam kurun waktu kurang lebih 1 minggu. Dari kasus tersebut, dapat kita ketahui bahwa terdapat kelemahan secara sistem dalam struktur organisasi Kimia Farma sehingga kasus antigen bekas ini bisa terjadi terjadi, dan hal ini sangat berdampak luas bagi kepercayaan masyarakat (Idris, 2021).

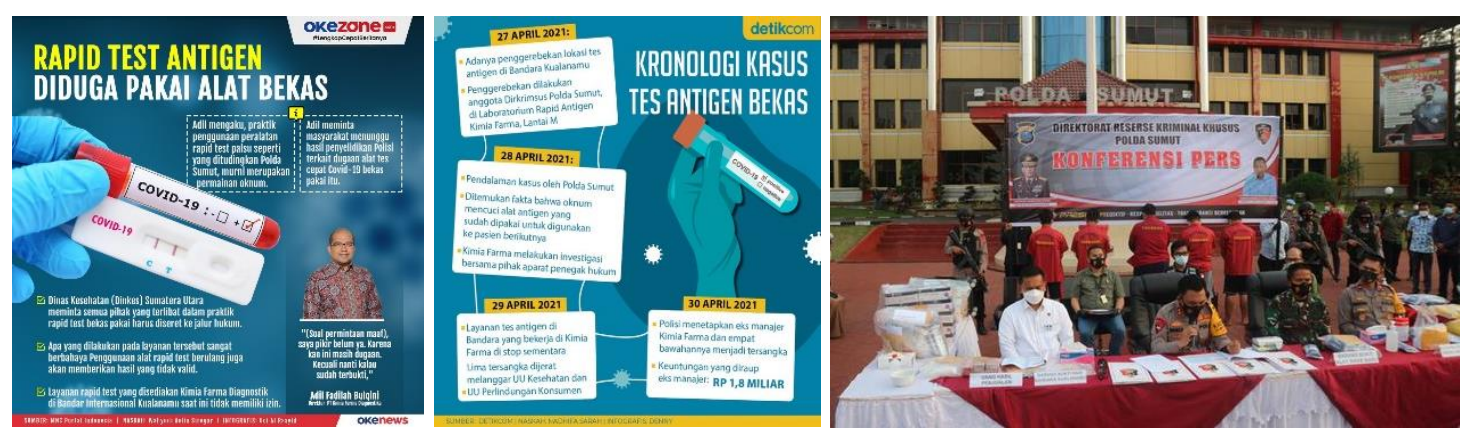

Gambar 4. Kasus antigen bekas dan penangkapan petugas terkait.

Untuk mendapatkan kembali kepercayaan masyarakat, pihak Kimia Farma ini langsung melakukan evaluasi serta melakukan penguatan terhadap pelaksanaan SOP (Standard Operating Procedure) dengan tujuan untuk memastikan bahwa seluruh dari kegiatan operasional perusahaann sudah sesuai ketentuan yang telah ditentukan dan yang pasti nya ketentuan tersebut berlaku. Kebijakan ini diambil oleh pihak Kimia Farma adalah sebagai upaya untuk melakukan pencegahan terhadap kejadian serupa tidak terjadi lagi.

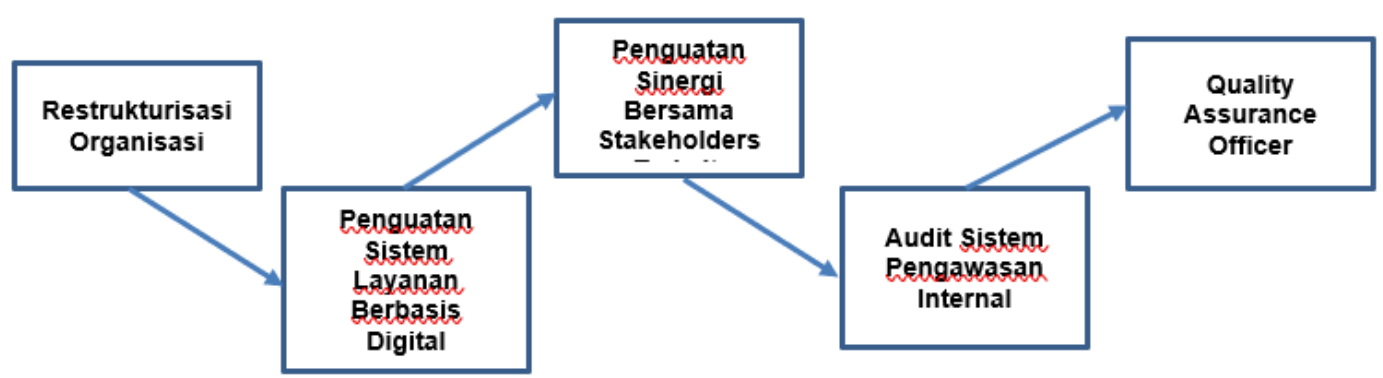

Gambar 5. Langkah pembenahan pencegahan terjadinya hal yang serupa 


\section{KESIMPULAN}

Kimia Farma adalah perusahaan yang berdiri pada tahun 1817 oleh pemerintah Hindia Belanda dengan nama NV Chemicalien Handle Rathkamp \& Co. dan menjadi perusahaan farmasi yang berdiri pertama kali di Indonesia. Kimia Farma juga termasuk BUMN terbesar yang dimiliki oleh pemerintah Indonesia, dimana pemerintah memiliki pengendalian terhadap perusahaan secara langsung dan tidak langsung. Kimia Farma juga memiliki enam strategi, yaitu New Bussiness Model with Digitalisation, Partnership Strategy, Operation Excellence \& Service Experience, Customer Relationship Management, Merchandising and Other Income Strategy, Cost Effectiveness, yang bisa menunjang pertumbuhan serta perkembangan perusahaan secara jangka panjang melalui Kimia Farma Apotek dan Kimia Farma Diagnostika yang merupakan perusahaan dari Kimia Farma.

Kimia Farma juga memiliki beberapa upaya dalam mengatasi kinerja keuangan yang sedang menurun akibat dari pandemi COVID-19, yaitu dengan meningkatkan layanan kepada masyarakat yang tidak mengunjungi langsung dengan meluncurkan aplikasi digital yang bernama "Kimia Farma Mobile", dimana aplikasi ini dikembangkan oleh Kimia Farma Apotek yang merupakan anak usaha dari Kimia Farma Aplikasi "Kimia Farma Mobile" ini diharapkan bisa menjadi solusi terkait penyediaan layanan kesehatan dimana aplikasi ini bisa digunakan oleh masyarakat dalam memperoleh bantuan serta kebutuhan mengenai kesehatan tubuh di masa pandemi. Selain itu, Kimia Farma juga melakukan optimalisasi layanan home service bagi para pasien yang mengalami keterbatasan dalam mengunjungi apotek Kimia Farma terdekat.

Dalam mengatasi kasus mengenai penggunaan antigen COVID-19 bekas kepada calon penumpang pesawat yang dilakukan oleh oknum pegawai atau petugas dari PT. Kimia Farma Diagnostika (KFD), menteri BUMN Erick Thohir menindaklanjuti secara tegas dengan mengeluarkan kebijakan dengan melakukan pemecatan terhadap seluruh direksi daripada PT. Kimia Farma Apotek, yang dimana saham dari PT tersebut dimiliki oleh BUMN farmasi. Kemudian itu, pihak Kimia Farma ini langsung melakukan evaluasi serta melakukan penguatan terhadap pelaksanaan SOP (Standard Operating Procedure) dengan tujuan untuk memastikan bahwa seluruh dari kegiatan operasional perusahaan sudah sesuai ketentuan yang telah ditentukan dan yang pasti nya ketentuan tersebut berlaku. Kebijakan ini diambil oleh pihak Kimia Farma adalah sebagai upaya untuk melakukan pencegahan terhadap kejadian serupa tidak terjadi lagi.

\section{DAFTAR PUSTAKA}

Caniago, D. (2017). Analisis perbandingan kinerja keuangan dengan menggunakan rasio keuangan tahun 2011-2015 (studi kasus PT. Kimia Farma Tbk dan PT. Indofarma Tbk). IAIN Padangsidimpuan.

Idris, M. (2021). Kinerja Keuangan Kimia Farma, BUMN yang Tersandung Kasus Antigen Bekas. Www.Money.Kompas.Com. https://money.kompas.com/read/2021/04/30/074630426/kinerjakeuangan-kimia-farma-bumn-yang-tersandung-kasus-antigen-bekas?page=all

kimiafarma.co.id. (2015). Sejarah Kimia Farma. Www.Kimiafarma.Co.Id. https://kimiafarma.co.id/index.php?option=com_content\&view=article\&id=1\&Itemid=252\&lang $=\mathrm{id}$

Mulyana, R. N. (2021). Kimia Farma merancang sejumlah strategi untuk bisa mengoptimalkan ekspansi tahun ini. Www.Newssetup.Kontan.Co.Id. https://newssetup.kontan.co.id/news/kimia-farmamerancang-sejumlah-strategi-untuk-bisa-mengoptimalkan-ekspansi-tahun-ini?page=all

Nursyamsi, M., \& Pratiwi, F. (2020). Kimia Farma Ungkap Dampak Pandemi Bagi Perusahaan. Www.Republika.Co.Id. https://www.republika.co.id/berita/qia9lp457/kimia-farma-ungkapdampak-pandemi-bagi-perusahaan

Sampurno, F. H. (2021). THE LAST CHANCE: KEBANGKITAN INDUSTRI STRATEGIS INDONESIA. Balai Pustaka (Persero), PT.

Sesyazhade, A. A., Setiawan, N. Y., \& Aknuranda, I. (2018). Analisis Variasi Proses Bisnis Manufaktur Dengan Menerapkan Process Mining (Studi Kasus: PT Kimia Farma, Tbk). Jurnal Pengembangan 
Teknologi Informasi Dan Ilmu Komputer E-ISSN, 2548, 964X.

Walintukan, M. R. (2019). ANALISIS PERBANDINGAN RASIO PROFITABILITAS PERUSAHAAN FARMASI PADA PT. KIMIA FARMA TBK DAN PT KALBE FARMA TBK PERIODE 2015-2017. STIE Indonesia Banjarmasin. 